\title{
Phyllachora maydis, Causal Agent of Tar Spot on Corn, Can Overwinter in Northern Illinois
}

\author{
Nathan M. Kleczewski, ${ }^{1,+}$ James Donnelly, $^{2}$ and Russ Higgins ${ }^{3}$ \\ ${ }^{1}$ University of Illinois Department of Crop Science, Urbana, IL 61801 \\ ${ }^{2}$ Bayer Crop Protection, Walnut, IL 61376 \\ ${ }^{3}$ University of Illinois Extension, Morris, IL 60450
}

Accepted for publication 14 June 2019.

Keywords: fungi, greenhouse method, cereals, Zea mays, ascospores

Tar spot on corn (Zea mays L.), caused by the obligate fungal pathogen Phyllachora maydis Maubl., was first detected in the United States in 2015 (Ruhl et al. 2016). P. maydis is the only member of the genus known to infect corn. It produces raised, black stromata on the surface of leaves, stalks, and husks (Kleczewski et al. 2019). Multiple perithecia are contained within a single stroma, which contain diagnostic ascospores that have a gold/orange coloration. Ascospores are the infective propagule, and under appropriate conditions, yield losses can be severe. Currently, the disease has been detected in 171 U.S. counties across Florida, Illinois, Indiana, Iowa, Michigan, Ohio, and Wisconsin (Kleczewski et al. 2019). In 2018, yield losses from tar spot across the affected states were estimated at 4,696,796 metric tons (Mueller et al. 2019). Although observations indicate that P. maydis overwinters in the region, this has not been conclusively proven. In mid-March 2019, once warming trends indicated corn planting would likely occur in early to mid-April, two samples of corn foliage heavily infested with $P$. maydis stromata were collected from DeKalb $\left(41.5337^{\circ} \mathrm{N}, 88.4613^{\circ} \mathrm{W}\right)$ and LaSalle $\left(41.4364^{\circ} \mathrm{N}, 88.9414^{\circ} \mathrm{W}\right)$ Counties in Illinois. Samples were placed in plastic bags and transferred on ice to the University of Illinois field crop pathology laboratory. Five symptomatic leaves for each sample were washed three times to remove surface debris and were surface sterilized for $30 \mathrm{~s}$ in a $10 \%$ bleach solution, followed by rinsing two times in sterile deionized (DI) water. Leaves were placed stromata side up into plastic containers containing damp paper towels and sealed to maintain near $100 \%$ humidity. Containers were allowed to incubate in the dark at $18^{\circ} \mathrm{C}$ for $48 \mathrm{~h}$ to hydrate the stromata. After $48 \mathrm{~h}$, white exudate containing ascospores of $P$. maydis was evident in 12 and $15 \%$ of stromata $(n=$ 100 per sample) for DeKalb and LaSalle samples, respectively. Spores were visualized and confirmed using light microscopy (Dalla Lana et al. 2019; Dittrich et al. 1991; Orton 1944; Ruhl et al. 2016). For each sample, leaves were blended in $500 \mathrm{ml}$ of sterile DI water plus a drop of Tween 20 using a hand blender. Residues were filtered through four layers of cheesecloth, and ascospores were adjusted to $1 \times 10^{4}$ ascospores $/ \mathrm{ml}$. For each spore source, ascospores were sprayed to wetness onto all sides of the foliage of three seedlings of Munson 6699 SS corn at the V4 growth stage. A seedling inoculated with water only was included as a nontreated control. Seedlings were transferred to a

${ }^{\dagger}$ Corresponding author: N. M. Kleczewski; E-mail: nathank@illinois.edu

The author(s) declare no conflict of interest.

(C) 2019 The American Phytopathological Society growth chamber set at $18^{\circ} \mathrm{C}$ and delivering 250 PAR on a 12-h day length. A cool mist humidifier was placed within the chamber and set to increase humidity to $100 \%$ for $8 \mathrm{~h}$ during the night period and every other hour during the day period. After 5 days, plants were transferred to a greenhouse set to maintain temperatures between 18 and $23^{\circ} \mathrm{C}$ and were watered as needed. Stromata were observed on foliage 17 days after inoculation (DAI), at $1 \%$ severity for both samples, and no symptoms were observed on nontreated controls. Stromata were excised and macerated to release ascospores at $30 \mathrm{DAI}$, in $1.5-\mathrm{ml}$ test tubes containing sterile distilled water, and $P$. maydis was confirmed through microscopy. This is the first report of overwintering $P$. maydis in U.S. corn production systems, indicating that the fungus can survive on corn residues for at least one winter under conditions in Northern Illinois. We also presented a method that could be adapted for studying $P$. maydis under controlled conditions. Although the severity of symptoms using our techniques was low, further optimization and research toward understanding factors that influence spore viability, germination, infection, and symptom development will enhance the method and its utility in studying this pathosystem. Additional work is needed to quantify the effects of management practices and environmental and edaphic factors on overwintering survival of $P$. maydis under Midwestern conditions and effects on disease management.

\section{Acknowledgments}

Many thanks to Alyssa Collins and two anonymous reviewers for edits and comments on preliminary drafts of this work.

\section{Literature Citec}

Dalla Lana, F., Plewa, D., Phillippi, E., Garzonio, D., Hesterman, R., Kleczewski, N., and Paul, P. 2019. First report of tar spot of maize (Zea mays) caused by Phyllachora maydis in Ohio. Plant Dis. 103:1780.

Dittrich, U., Hock, J., Kranz, J., and Renfro, B. 1991. Germination of Phyllachora maydis ascospores and conidia of Monographella maydis. Cryptogam. Bot. 2:214-218.

Kleczewski, N. M., Chilvers, M., Mueller, D. S., Plewa, D., Robertson, A. E., Smith, D. L, and Telenko, D. 2019. Corn disease management: Tar spot. CPN 2012-W. Crop Protection Network.

Mueller, D. S., Wise, K. A., and Sisson, A. 2019. Corn disease management-Corn disease loss estimates from the United States and Ontario, Canada-2018. CPN 2007-18. Crop Protection Network.

Orton, C. R. 1944. Graminicolous species of Phyllachora in North America. Mycologia 36:18-53.

Ruhl, G., Romberg, M. K., Bissonnette, S., Plewa, D., Creswell, T., and Wise, K. A. 2016. First report of tar spot on corn caused by Phyllachora maydis in the United States. Plant Dis. 100:1496-1497. 